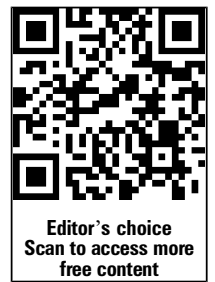

${ }^{1}$ Department of Oral Medicine and Radiology, College of Dental Science and Research Center, Ahmedabad, Gujarat, India

${ }^{2}$ Department of Paediatric Dentistry, College of Dental Science and Research Center, Ahmedabad, Gujarat, India ${ }^{3}$ AECS Maruti Dental College, Bangalore, Karnataka, India

\section{Correspondence to}

Dr Cheranjeevi Jayam, cheranjeevij@gmail.com

Accepted 23 May 2014

\title{
An unusual presentation of peripheral ossifying fibroma in an elderly man
}

\author{
Yuvaraj Suryakant Parmar, ${ }^{1}$ Vivek Muljibhai Tarsariya, ${ }^{1}$ Cheranjeevi Jayam, ${ }^{2}$ \\ Anila Bandlapalli ${ }^{3}$
}

\section{SUMMARY}

Peripheral ossifying fibroma is a common solitary gingival overgrowth thought to arise from the gingival corium, periosteum or periodontal ligament. Ossifying fibroma has the propensity to occur in cranial bones, but the peripheral variety shows a close relationship with the periodontal ligament and adjacent alveolar bone. It is more commonly seen in women (predilection of 3:1) and usually at a young age. This report describes an unusual presentation in an elderly man and presents a systematic way of diagnosing and treating peripheral ossifying fibroma.

\section{BACKGROUND}

Peripheral ossifying fibroma (POF) is a nonneoplastic enlargement of the gingiva and is believed to comprise about $9 \%$ of all gingival growths. ${ }^{1}$ Intraoral ossifying fibromas have been described in the literature since the late 1940s. Many names have been given to similar lesions such as epulis, peripheral fibroma with calcification, POF, peripheral cementifying fibroma and peripheral fibroma with cementogenesis. ${ }^{2}$ The term POF was first coined by Eversole and Rovin. ${ }^{3}$ Aetiological factors for POF include precipitating factors such as local irritation and minor trauma. ${ }^{4}$ It is typically seen as an exophytic growth on the interdental papilla appearing as a nodular mass, either pedunculated or sessile. The colour ranges from red to pink and the surface is frequently but not always ulcerated. It is more commonly seen in the first and second decades of life and has a female preponderance. A slight predilection for the maxillary arch and the incisor cuspid region has also been noted. ${ }^{5}$ Due to its growth, it is often mistaken for a cancerous lesion for which the patient commonly reports.

We report a case of POF in a 62-year-old man and demonstrate a systematic way of diagnosing and treating such lesions. The importance of a reasonable differential diagnosis, adequate radiographic investigation and appropriate interpretation in forming a diagnosis is highlighted. Recommendations regarding treatment and follow-up have also been included.

\section{CASE PRESENTATION}

A 62-year-old man reported to the Department of Oral Medicine and Radiology with a six-month history of a painless growth in the lower front tooth region for the previous 6 months. The lesion started as a small painless peanut-sized nodule in the midline of the mandible in the region of the incisors but suddenly increased in size (figure 1). The patient was anxious about this enlarging mass, so he reported to our department for treatment. On further questioning there was no history of bleeding, pain or paraesthesia. The prior dental history revealed extraction of the lower left front tooth 1 year previously. The medical history was unremarkable.

Intraoral examination revealed a solitary round exophytic nodular soft tissue growth in the region of teeth 32, 41 and 42 (FDI system of tooth notation) which was crossing the midline (figure 2). The growth was bright red in colour with a lobulated surface measuring $4 \times 3 \mathrm{~cm}$ with a welldefined periphery. On palpation, the growth was slightly tender with a pedunculated base and slightly movable. Other dental findings included the absence of tooth 31 . There was severe calculus build-up and signs of severe periodontitis. Lymph node examination was unremarkable.

\section{PROVISIONAL DIAGNOSIS}

Based on the above findings, a provisional diagnosis of pyogenic granuloma was assumed.

\section{DIFFERENTIAL DIAGNOSIS}

POF, inflammatory gingival enlargement and peripheral giant cell granuloma and metastatic malignant growth were considered in the differential diagnosis.

\section{INITIAL INVESTIGATION}

The investigatory work-up included a complete haemogram, radiographs and excisional biopsy of the lesion. Periapical radiographs in the region of

Figure 1 Exophytic growth in the mandibular anterior region crossing the midline (labial view). 
Figure 2 Mesiodistal and labiolingual extension of the growth.

teeth $33,32,41$ and 42 showed a scooped out area of bone rarefaction at the periapical region (figure 3 ). Radiographic findings included the presence of a shadow of the mental triangle superimposed over the shadow of bone destruction. The shadow of the inferior border of the mandible did not reveal any abnormality. Divergence of the crown with respect to the grey shadow of the nodule was evident with teeth 32 and 41. Routine haematological values were within normal limits.

\section{TREATMENT}

The proposed treatment was excisional biopsy with deep scaling and curettage.

The patient was evaluated for fitness to undergo a surgical procedure. Scaling and other oral prophylactic procedures were

Figure 3 Periapical radiograph of teeth 33, 32, 41 and 42 showing a scooped out area of bone rarefaction in the periapical region. completed before initiating surgery. Surgery was performed under local anaesthesia. A suture was placed on the lesion to enable the growth to be grasped, allowing proper access to the pedunculated stalk. This manoeuvre permitted proper performance of excisional biopsy. The excision was planned so that the whole growth was removed in total with good margins to avoid future recurrence and the excised tissue was sent for radiological and histopathological investigations.

\section{Radiological and histopathological investigations}

The excised specimen was radiographed at low exposure, revealing an area of opacification comparable with the shadow of osseous tissue (the importance of low exposure was to evaluate the presence of any calcific flecks which would not be seen with regular exposure; figure 4).

Histopathological examination showed the presence of connective tissue with high collagen fibres, proliferating fibroblasts and intense infiltration by chronic inflammatory cells. Irregular multiple foci of homogenous calcified areas were evident within the connective tissue (figure 5).

\section{FINAL DIAGNOSIS}

Based on all the findings, a final diagnosis of POF was made.

\section{DISCUSSION}

The aetiopathogenesis of POF is uncertain, although an origin from the cells of the periodontal ligament has been suggested. ${ }^{6}$ POF occurs more commonly in women and in the second decade, hence the role of hormones has also been questioned. However, our case was a 62 -year-old man. ${ }^{7}$ The clinical features of POF were described by Buchner and Hansen, and consist of a localised growth on the gingiva with a pedunculated or sessile base. $^{8}$ Approximately $60 \%$ of POFs occur in the maxilla and they are more often found in the anterior region, with 55-60\% presenting in the incisor-cuspid region. ${ }^{9}$ However, in our case the growth presented in the mandibular gingiva in the incisor region. It usually measures less than $1.5 \mathrm{~cm}$ and rarely reaches more than $3 \mathrm{~cm}$ in diameter, but lesions of 6 and $9 \mathrm{~cm}$ have also been reported. ${ }^{10}$ Multicentric POF can also occur in the oral and maxillofacial region, and have been observed in conditions associated with known genetic mutations such as naevoid basal cell carcinoma syndrome, multiple endocrine neoplasia type II, neurofibromatosis and Gardner syndrome. ${ }^{6}$ Although radiographic changes are not always seen with POF, foci of

Figure 4 Radiograph of excised growth at low exposure showing opaque areas comparable with the shadow of the osseous tissue. 
Figure 5 Histopathology showing homogenous calcified areas.

radiopaque material may occasionally be seen, particularly in large lesions or lesions with overt mineralisation, as in our case. $^{6}$ A mild cupping defect of the adjacent alveolar bone along with migration of teeth with interdental bone destruction can be seen in some cases. Migration of teeth with appreciable interdental bone loss was present in our case. ${ }^{9}$

Histologically, POF is composed of cellular fibrous tissue with areas of fibrovascular tissue that often contain an inflammatory component with abundant plasma cells. An intact or ulcerated stratified squamous epithelium and endothelial proliferation is usually observed. Ossification from small rounded calcified deposits to large trabecular bone areas surrounded by osteoblasts may be seen. ${ }^{11}$ The clinical differential diagnosis includes peripheral giant cell granuloma, pyogenic granuloma, fibroma and peripheral odontogenic fibroma. Peripheral giant cell granuloma has clinical features similar to those of POF, but the latter lacks the purple or blue discolouration associated with peripheral giant cell granuloma and radiographically shows small flecks of calcification. ${ }^{12}$ Pyogenic granulomas are usually very small (from a few millimetres to $1 \mathrm{~cm}$ ) and only occasionally show calcification. However, some researchers believe that POF is related to pyogenic granuloma and is probably a mature pyogenic granuloma containing fibrosis and calcification. ${ }^{4}$

The prognosis of POF is good, but some instances of recurrence have been reported. The recommended treatment is local surgical excision extending to include the periosteum with submission for histomorphological examination and scaling of the adjacent teeth. ${ }^{2}$ Inclusion of the periosteum during the excision decreases the recurrence of this lesion. Recurrence may reflect incomplete initial removal or repeated injury. ${ }^{8}$

\section{CONCLUSION}

POF is a slowly progressing lesion. Many cases will progress for long periods before the patient seeks treatment because of the lack of symptoms associated with the lesion. Without treatment the lesion can increase in size and interfere with normal mastication, thereby necessitating early diagnosis and initiation of effective treatment. Close postoperative follow-up is required because of the growth potential of incompletely removed lesions and a high recurrence rate.

\section{Learning points}

- Peripheral ossifying fibroma mimics many soft tissue growths; diagnosis is only possible by radiological and histopathological examination.

- It is mandatory to perform radiological and histological examination to assess the nature of the growth.

- Proper excision is required to prevent recurrence of the lesion.

Competing interests None.

Patient consent Obtained.

Provenance and peer review Not commissioned; externally peer reviewed.

\section{REFERENCES}

1 Sharma S, Sharma A, Ramachandra SS. Peripheral ossifying fibroma: a clinical report. Compend Contin Educ Dent 2011;32:E86-90.

2 Farquhar T, MacLellan J, Dyment $\mathrm{H}$, et al. Peripheral ossifying fibroma: a case report. J Can Dent Assoc 2008;74:809-12.

3 Eversole LR, Rovin S. Reactive lesions of the gingiva. J Oral Pathol 1972;1:30-8.

4 Moon W-J, Choi SY, Chung EC, et al. Peripheral ossifying fibroma in the oral cavity: CT and MR findings. Dentomaxillofac Radiol 2007;36:180-2.

5 Neville BW, Damm DD, Allen CM, et al. Soft tissue tumours. In: Oral and maxillofacial pathology. 2nd edn. Philadelphia: Saunders, 2002:451-2.

6 Kumar SK, Ram S, Jorgensen MG, et al. Multicentric peripheral ossifying fibroma. J Oral Sci 2006;48:239-43.

7 Miller CS, Henry RG, Damm DD. Proliferative mass found in the gingival. J Am Dent Assoc 1990;121:559-60.

8 Kohli K, Christian A, Howell R. Peripheral ossifying fibroma associated with a neonatal tooth: case report. Am Acad Pediatr Dent 1998;20:428-9.

9 Singh AP, Raju MS, Mittal M. Peripheral ossifying fibroma: a case report. J Nepal Dent Assoc 2010;11:70-2.

10 Prasad S, Reddy SB, Patil SR, et al. Peripheral ossifying fibroma and pyogenic granuloma. Are they interrelated? N Y State Dent J 2008;74:50-2.

11 García de Marcos JA, García de Marcos MJ, Arroyo Rodríguez S, et al. Peripheral ossifying fibroma: a clinical and immunohistochemical study of four cases. J Oral Sci 2010;52:95-9.

12 Das UM, Azher U. Peripheral ossifying fibroma. J Indian Soc Pedod Prev Dent 2009;27:49-51. 
Copyright 2014 BMJ Publishing Group. All rights reserved. For permission to reuse any of this content visit http://group.bmj.com/group/rights-licensing/permissions.

BMJ Case Report Fellows may re-use this article for personal use and teaching without any further permission.

Become a Fellow of BMJ Case Reports today and you can:

- Submit as many cases as you like

- Enjoy fast sympathetic peer review and rapid publication of accepted articles

- Access all the published articles

- Re-use any of the published material for personal use and teaching without further permission

For information on Institutional Fellowships contact consortiasales@bmjgroup.com

Visit casereports.bmj.com for more articles like this and to become a Fellow 